\title{
Pengaruh Audit Manajemen, Komitmen Organisasional Manajer, dan Pengendalian Internal Terhadap Penerapan Prinsip-Prinsip Good Corporate Governance
}

\author{
Mu'amar, Dhaniel Syam, Siti Zubaidah \\ Program Studi Akuntansi Fakultas Ekonomi dan Bisnis \\ Universitas Muhammadiyah Malang \\ Jl. Raya Tlogomas No.246 Malang
}

\begin{abstract}
Abstrack
This study aims to examine the effect of Management Audit, Organizational Commitment Manager, Internal Control Against Application of Principles of Good Corporate Governance. The sample of this study is 62 manufacturing companies listed in Indonesia Stock Exchange (BEI) in 2013 with purposive sampling technique.. The data was analized with logistic regression. The result showed that management audit has no effect on the implementation of good corporate governance principles, organizational commitment of managers has an effect on the application of the principle of good corporate governance, and internal control does not affect the implementation of good corporate governance principles.
\end{abstract}

Keyword: Management Audit, Organizational Commitment Manager, Internal Control, Principles of Good Corporate Governance.

\section{PENDAHULUAN}

Di Indonesia konsep good corporate governance mulai banyak diperbincangkan pada pertengahan tahun 1997, saat itu krisis ekonomi melanda negara ini. Dampak dari krisis tersebut menunjukkan bahwa banyak perusahaan yang tidak mampu bertahan. Berdasarkan kondisi tersebut, pemerintah Indonesia dan lembaga-lembaga keuangan internasional memperkenalkan konsep good corporate governance. Dalam rangka economy recovery, pemerintah Indonesia dan International Monetary Fund (IMF) memperkenalkan dan menjelaskan konsep good corporate governance sebagai tata cara kelola perusahaan yang sehat (Sulistyanto dan Lidyah. 2002). Konsep ini diharapkan dapat melindungi pemegang saham (stockholders) dan kreditur agar dapat memperoleh kembali investasinya.

Menurut Forum for Corporate Governance in Indonesia (2001) melalui penerapan good corporate governance tersebut diharapkan: (1) perusahaan mampu meningkatkan kinerjanya melalui terciptanya proses pengambilan keputusan yang lebih baik, meningkatkan efisiensi operasional perusahaan, serta mampu meningkatkan pelayanannya kepada stakeholders; (2) perusahaan lebih mudah memperoleh dana pembiayaan yang lebih murah sehingga dapat meningkatkan corporate value; (3) mampu meningkatkan kepercayaan investor untuk menanamkan modalnya di Indonesia; dan (4) pemegang saham akan merasa puas dengan kinerja perusahaan sekaligus akan meningkatkan shareholders value dan dividen (Meythi dan Devita, 2013). Pemerintah dalam mendukung penerapan prinsip-prinsip good corporate governance tersebut dengan memperbaharui UU Nomor Kep-117/MMBU/2002 tanggal 31 Juli 2002 dengan Nomor Per-01/MBU/2011 (Kementrian BUMN, 2011).

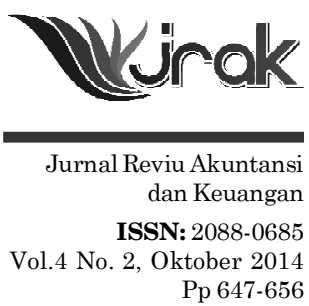




\section{Pengaruh Audit \\ Manajemen...}

Secara teoritis buruknya good corporate governance di Indonesia tidak terlepas dari pelaksanaan pengendalian internal (Pratolo, 2007). Dari lima komponen pengendalian internal tersebut lingkungan pengendalian merupakan dasar dalam pengendalian karena memengaruhi kesadaran pihak-pihak yang ada di dalam perusahaan (Agoes, 2012). Berbicara tentang pengendalian internal tidak dapat dilepaskan dengan audit. Untuk mencapai tujuan organisasi secara efektif diperlukan fungsi audit manajemen yang berfungsi untuk membantu manajer dan dewan komisaris dalam mencapai pengelolaan yang optimal dalam pelaksanaan tugas yang menjadi tanggung jawab mereka (Sawyer et al. 2005).

Pelaksanaan prinsip-prinsip good corporate governance maupun pengendalian internal tidak terlepas juga dari aspek personil yang ada dalam perusahaan. Karena sebaik apapun suatu sistem dibangun, namun bila para personilnya tidak memiliki komitmen bersama untuk menjaga keberlangsungan perusahaan, maka sistem tersebut tidak akan efektif (Pratolo (2007). Terdapat berbagai faktor yang dapat mempengaruhi penerapan prinsip-prinsip good corporate governance pada perusahaan. Penelitian yang dilakukan oleh Pratolo (2007) membuktikan bahwa audit manajemen, dan komitmen organisasional manajer tidak berpengaruh terhadap penerapan prinsip-prinsip good corporate governance. Penelitian Wiratno et al. (2013) membuktikan komitmen organisasi dan pengendalian internal berpengaruh positif terhadap penerapan prinsip-prinsip good corporate governance. Penelitian Saptapradipta (2014) membuktikan bahwa audit internal, pengendalian internal berpengaruh dan signifikan terhadap penerapan good corporate governance. Penelitian Ristanti et al. (2014) membuktikan bahwa pengendalian internal berpengaruh berpengaruh positif dan signifikan terhadap penerapan good corporate governance.

Berdasarkan penjelasan diatas penelitian ini dilakukan dengan tujuan untuk menemukan bukti empiris mengenai pengaruh auditing manajemen, komitmen organisasional manajer, pengendalian internal terhadap penerapan prinsip-prinsip good corporate governance pada perusahaan pemanufakturan.

\section{PERUMUSAN HIPOTESIS}

Hasil penelitian yang telah dilakukan oleh Hariati dan Olivani (2013) dan Sapta pradipta (2014) menyataka bahwa audit manajemen berpengaruh signifikan terhadap penerapan prinsip-prinsip good corporate governance. Sementara itu, hasil penelitian yang dilakukan oleh Pratolo (2007) yang menyatakan bahwa audit manajemen tidak berpengaruh secara langsung terhadap penerapan prinsipprinsip good corporate governance.

$\mathrm{H}_{1}$ : audit manajemen berpengaruh terhadap penerapan prinsip-prinsip good corporate governance.

Hasil penelitan yang dilakukan oleh Konzelmen (2005) dan Wiratno et al. (2014) menyatakan bahwa komitmen organisasional manajer berpengaruh positif dan terhadap penerapan prinsip-prinsip good corporate governance. Sementara itu, penelitian yang dilakukan oleh Pratolo (2007) menyatakan tidak pengaruh secara langsung komitmen organisasional manajer terhadap penerapan prinsipprinsip good corporate governance, disebabkan komitmen organisasional manajer yang cukup tinggi sehingga tidak diimbangi dengan kemandirian perusahaan. Pengembangan hipotesis penelitian ini sesuai dengan yang dilakuka oleh Konzelmen (2005) dan Wiratno et al. 2014).

$\mathrm{H}_{2}$ : terdapat pengaruh positif dan signifikan terhadap komitmen manajer pada organisasi terhadap penerapan prinsip-prinsip good corporate governance.

Hasil penelitian yang telah dilakukan oleh Hariati dan Oliviani (2013) dan Widjaja dan Mustamu (2014) menyatakan bahwa pengendalian internal memiliki 
pengaruh positif terhadap penerapan good corporate governance. Sementara itu, belum ada penelitian yang menyatakan bahwa tidak ada pengaruh pengendalian internal terhadap penerapan prinsip-prinsip good corporate governance. Pengembangan hipotesis penelitian ini sesuai telah dilakukan oleh Hariati dan Oliviani (2013), dan Widjaja dan Mustamu (2014).

$\mathrm{H}_{3}$ : terdapat pengaruh positif terhadap pengendalian intern penerapan prinsipprinsip good corporate governance.

Terdapat pengaruh positif antara audit manajemen, komitmen manajer pada organisasi, pengendalian internal terhadap penerapan prinsip-prinsip good corporate governance sesuai yang telah dilakukan oleh Hariati dan Oliviani (2013), Widjaja dan Mustamu (2014) dan Saptapradipta (2014).

$\mathrm{H}_{4}$ : terdapat pengaruh positif dan signifikan terhadap terdapat pengaruh positif terhadap pengendalian intern penerapan prinsip-prinsip good corporate governance.

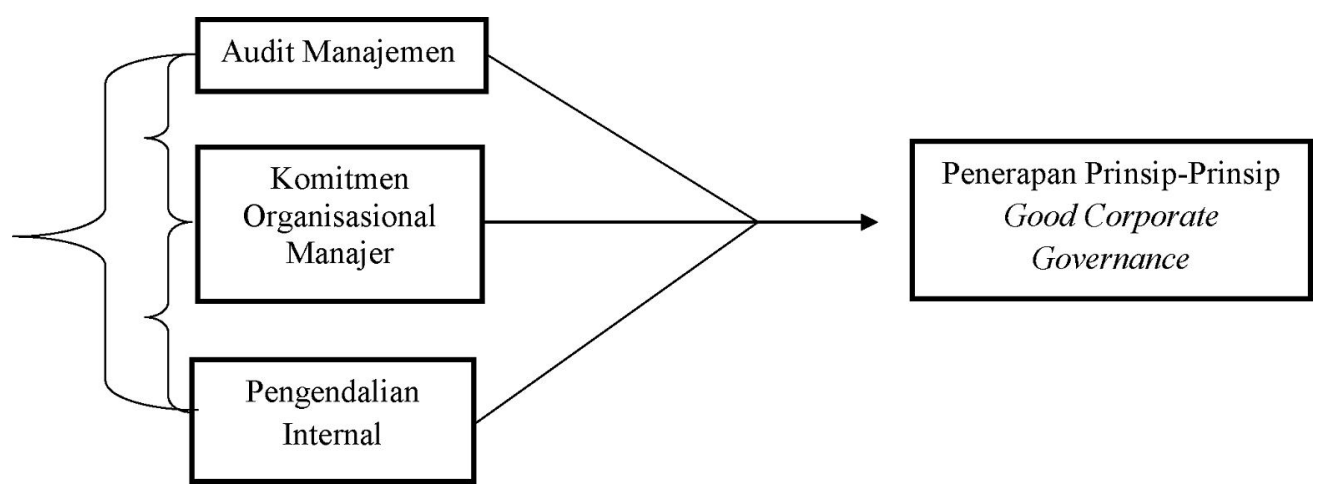

\section{METODE PENELITIAN}

Obyek penelitan ini adalah perusahaan pemanufakturan yang terdaftar di Bursa Efek Indonesia pada tahun 2013. Jenis penelitiannya adalah asosiatif karena menjelaskan hubungan antara dua varaibel atau lebih (Sugiyono, 2014). Varibel dependen dalam peneitian ini adalah audit manajemen yang diukur menggunakan skala rasio. Skala rasio adalah skala yang dapat dibagi, dikurang, dan ditambah (Agustine dan Kristaung, 2013). Pengukuran untuk ekonomisasi, efisiensi dan efektivitas dapat menggunakan rasio aktivitas. Manajer pada organisasi diukur menggunakan skala nominal, adalah skala pengukuran yang dinyatakan dengan kategori, sedangkan sifat kategori saling mentiadakan (mutually exclusive) dan juga menyatakan kategori bersifat (collectively exhaustive) (Indiantoro dan Supomo, 2009). Pengendalian internal diukur berdasarkan hasil dari laporan audit dan auditor memberikan pernyataan wajar tanpa pengecualian. Sedangkan variabel independen dalam penelitian ini adalah penerapan prinsi-prinsip good corporate governance yang diukur menggunakan skala nominal, dengan ketentuan yang dibuat oleh Bapepam- LK yaitu setiap emiten atau perusahaan wajib untuk mengungkap pelaksanaan tata kelola perusahaan dalam laporan tahunan seperti frekuensi rapat dewan komisaris dan direksi, frekuensi kehadiran anggota dewan komisaris dan direksi dalam rapat tersebut, frekuensi rapat dan kehadiran komite audit, pelaksanaan tugas dan pertanggungjawaban dewan komisaris dan deriksi serta remunerasi dewan komisaris dan direksi (Bapepam-LK, 2010).

Dalam penelitian ini populasi yang digunakan adalah semua perusahaan manufaktur yang terdaftar di Bursa Efek Indonesia pada tahun 2013 yang jumlahnya sebanyak 137 perusahaan, penelitian ini menggunakan tehnik pemilihan sampel bertujuan (purposive sampling) sehingga diperoleh 62 sampel. Data yang digunakan adalah data sekunder yang berupa annual report tahun 2013 (laporan tahunan) perusahaan manufaktur.
Gambar 1.

Kerangka Pemikiran 


\section{Pengaruh Audit \\ Manajemen...}

\section{Analisis data dilakukan dengan tahapan sebagai berikut:}

1. Identifikasi Variabel

a. Mengidentifiakasi audit manajemen yaitu menggunkan rasio aktivitas yang terdiri dari: rasio perputaran piutang, rasio perputaran persediaan, rasio perputaran aset tetap, rasio perputaran total aset.

b. Mengidentifikasi komitmen orgnisasional manajer dengan menelaah laporan tahunan perusahaan.

c. Mengidentifikasi pengendalian internal dilihat dari laporan tahunan berupa pernyataan audit independen.

d. Mengidentifikasi penerapan prinsip-prinsip good corporate governance.

2. Statistik Deskriptif

Mentransformasi data penelitian dalam bentuk tabulasi. Bertujuan untuk memudahkan dalam memahami dan menginterpretasikan. Adapun ukuran yang digunakan dalam statistik deskriptif adalah (rata-rata, median, modus, standar devisiasi, varian, dan koofisien korelasi antara variabel penelitian (Indiantoro dan Supomo, 2009).

3. Uji Hipotesis

a. Regresi Logistik

Regresi logistik adalah pengukuran yang digunakan untuk variable dependennya berupa variabel dikatomi (kategori) (Ghozali, 2011). Dalam analisis regresi logistik tidak diperlu dilakukan uji normalitas dikarenakan distribution variabel bebasnya merupakan campuran antara variabel kontinyu (matrik) dan kategorial (non-matrik) (Ghozali, 2011).

Model dari penelitian ini dengan menggunakan regresi logistik sebagai berikut:

$\mathrm{Ln}=\mathrm{a}+$ pi $\mathrm{X} 1+P 2 \mathrm{X} 2+£ 3 \mathrm{X} 3+\mathrm{e}$.

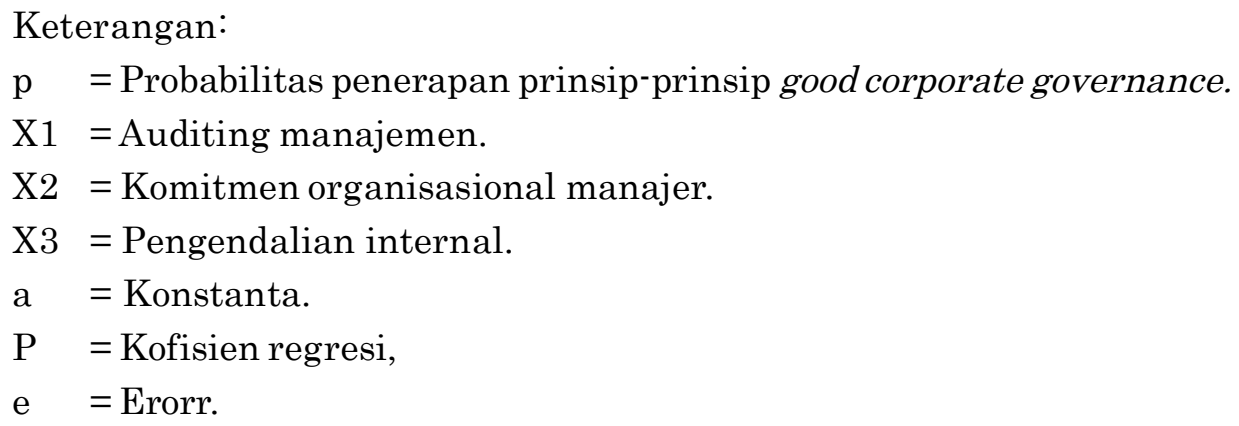

b. Uji Signifikan Model Regresi Logistik

Langkah pertama dalam uji signifikan model regresi logistik yaitu:

1) Menilai model fit

Langkah pertama adalah menilai overall fit model terhadap data, sedangkan hipotesis untuk menilai model fit yaitu:

$\mathrm{H}_{0}$ : Model yang dihipotesakan fit dengan data.

$\mathrm{H}_{\mathrm{a}}$ : Model yang dihipotesakan tidak fit dengan data.

Arti pernyataan diatas adalah ketika H0 diterima maka model fit dengan data, sedangkan Ha diterima maka model tidak fit dengan data. Fungsi statistik yang digunakan adalah fungsi likelihood. Likelihood L ditransformasikan menjadi -2LogL, adapun L dari model merupakan probabilitas dari data yang diinput dan berfungsi untuk menguji hipotesis nol dan hipotesis alternatif.

Dalam output SPSS, akan memberikan dua -2LogL untuk menguji model fit dengan data: 
a) Jika -2LogL $>0,05$ maka H0 ditolak model tidak fit dengan data.

b) Jika -2LogL yang pertama > -2logL kedua maka H0 diterima,

2) Estimasi Parameter dan Interpretasinya.

Estimasi parameter model dapat dilihat pada output variable in the equition.

\section{HASIL DAN PEMBAHASAN}

\section{Statistik Deskriptif}

\begin{tabular}{lcccrrr}
\hline & N & Minimum & Maximum & Sum & Mean & $\begin{array}{c}\text { Std. } \\
\text { Deviation }\end{array}$ \\
\hline Per_Piut & 62 & .52 & 29.73 & 468.24 & 7.5523 & 5.88054 \\
Per_Pers & 62 & 1.08 & 34.73 & 328.04 & 5.2910 & 5.12979 \\
Per_AT & 62 & .02 & 13.74 & 215.56 & 3.4768 & 3.08755 \\
Per_TA & 62 & .02 & 2.61 & 66.50 & 1.0726 & .58261 \\
Valid N & 62 & & & & & \\
(listwise) & & & & & &
\end{tabular}

Tabel 1.

Statistik Deskriptif

Sumber: Output SPSS

Tabel 1. merupakan rasio aktivitas perusahaan yang menjadi sampel penelitian. Rasio aktivitas terdiri dari perputaran piutang, perputaran persediaan, perputaran aset lancar, dan peputaran total aset. Perputaran piutang tertinggi PT. Trias Sentosa Tbk. sebesar 29.73 kali pertahun dan terendah PT. Davomas Abadi Tbk. sebesar 0.52 kali pertahun dengan rata-rata perputaran piutang perusahaan sebesar 7.55 kali pertahun. Perputaran persediaan tertinggi PT. Hanson International Tbk. sebesar 34.73 kali pertahun dan terendah PT. Multi Prima Sejahtera Tbk. sebesar 1.08 kali pertahun dengan rata-rata perputaran persedian perusahaan sebesar 5.29 kali pertahun. Perputaran aset tetap tertinggi sebesar 13.74 kali per- $^{-}$ tahun dan terendah PT. Kertas Basuki Rachmat Indonesia Tbk. sebesar 0.02 kali pertahun dengan rata-rata perputaran aset tetap sebesar 3.48 kali pertahun. Perputaran total aset tertinggi PT. Sekar Bumi Tbk. sebesar 2.61 kali pertahun dan terendah PT. Kertas Basuki Rachmat Indonesia Tbk. sebesar 0.02 kali pertahun dengan rata-rata perputaran total aset sebesar 1.07 kali pertahun.

\section{Hasil Uji Hipotesis $\alpha$}

Menilai Model Fit

\begin{tabular}{ccc}
\hline & & Coefficients \\
\cline { 3 - 3 } Iteration & -2 Log likelihood & Constant \\
\hline Step & 38.016 & 1.677 \\
3 & 34.914 & 2.256 \\
4 & 34.763 & 2.421 \\
5 & 34.762 & 2.434 \\
& 34.762 & 2.434
\end{tabular}

Tabel 2.

Likelihood Dengan Konstanta.

Sumber: Output SPSS.

Uji regresi logistik akan menghasilkan dua likelihood yang ditranformasikan menjadi -2LogL berfungsi untuk menguji hipotesis nol dan hipotesis alternatif. 2LogL yang petama adalah likelihood dengan konstanta dan yang kedua likelihood dengan kosntanta dan variable bebas atau independen. Table 2. merupakan 


\section{Pengaruh Audit \\ Manajemen...}

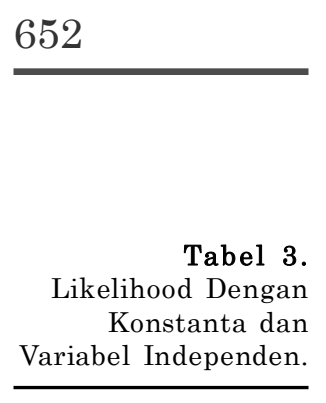

Tabel 4. Cox \& Snell R Square.

Tabel 5 . Goodness of Fit Tes
-2LogL pertama dengan konstanta menunjukan nilai sebesar 34,762. Pada likelihood pertama ketentuan hipotesis nol diterima apa bila nilai signifikansinya < 0.05 , yang berarti hipotesis nol ditolak dan hipotesis alternatif diterima berarti model tidak fit dengan data.

\begin{tabular}{|c|c|c|c|c|c|c|c|c|}
\hline \multirow[b]{2}{*}{ Iteration } & \multirow{2}{*}{$\begin{array}{c}-2 \text { Log } \\
\text { likelihood }\end{array}$} & \multicolumn{7}{|c|}{ Coefficients } \\
\hline & & Consta & Per_P & Per_Pe & Per_A & Per_T & Komit & $\mathrm{PI}$ \\
\hline Step 11 & 29.754 & 102 & -.016 & .022 & -.068 & .268 & 1.740 & .062 \\
\hline 2 & 21.948 & .000 & -.035 & .053 & -.156 & .591 & 2.824 & .055 \\
\hline 3 & 19.832 & -.067 & -.058 & .090 & -.255 & .965 & 3.723 & -.076 \\
\hline 4 & 19.441 & -.097 & -.075 & .114 & -.326 & 1.272 & 4.305 & -.237 \\
\hline 5 & 19.418 & -.105 & -.081 & .121 & -.348 & 1.380 & 4.495 & -.299 \\
\hline 6 & 19.418 & -105 & -.082 & .122 & -.350 & 1.389 & 4.510 & -.305 \\
\hline 7 & 19.418 & -.105 & -.082 & .122 & -.350 & 1.389 & 4.510 & -.305 \\
\hline
\end{tabular}

Tabel 4.10.merupakan likelihood kedua hasil dari aplikasi SPSS, yaitu likelihood dengan konstanta dan variable bebas menunjukan nilai dari sebesar 20.06. Pada likelihood kedua ketentuannya yaitu jika -2LogL pertama > -2LogL kedua maka hipotesis nol diterima dan hipotesis alternatif ditolak yang berarti model fit dengan data.

\begin{tabular}{cccc}
\hline Step & -2 Log likelihood & Cox \& Snell R Square & Nagelkerke R Square \\
\hline 1 & $19.418^{*}$ & .219 & .511 \\
\hline Sumber: Output & SPSS. & &
\end{tabular}

Tabel 4. diatas merupakan seberapa besar variable independen dapat menjelaskan variable dependen. Pada tabel nilai nagelkerke $R$ square sebesar 0,493. Hal ini bermakna bahwa variable independen yaitu audit manajemen terdiri dari rasio aktivitas, komitmen organisasional manajer dan pengendalian internal dapat menjelaskan terhadap variable dependen yaitu penerapan prinsip-prinsip good corporate governance sebesar 49 , 3\% dan 50,7\% dijelaskan oleh faktor lain.

\begin{tabular}{l|r|r|r|}
\hline Step & Chi-square & \multicolumn{1}{c|}{ df } & \multicolumn{1}{c|}{ Sig. } \\
\hline 1 & 10.580 & 8 & .227 \\
\hline
\end{tabular}

Tabel Goodness of Fit Tes berfungsi sebagai penguji hipotesis nol, dimana data fit dengan model atau tidak ada perbedaan model dengan data. Dengan ketentuan jika nilai Hosmer dan Lemeshow Goodness of Fit Tessama atau kurang dari 0.05, maka hipotesis nol ditolak yang berarti ada perbedaan signifikan antara model dengan nilai observasinya. Tabel 5. menunjukan bahwa nilai Chi-Square pada tabel Hosmer dan Lemeshow Goodness of Fit Tes sebesar 10.580 dengan tingkat signifikannya sebesar 0.227 dimana tingkat signifikansinya lebih besar dari 0.05 maka hipotesis nol diterima, berarti model fit karena mampu menjelaskan nilai observasinya.

\begin{tabular}{|c|c|c|c|}
\hline \multirow[b]{3}{*}{ Observed } & \multicolumn{3}{|c|}{ Predicted } \\
\hline & \multicolumn{2}{|c|}{ PGCG } & \multirow{2}{*}{$\begin{array}{c}\text { Percentage } \\
\text { Correct }\end{array}$} \\
\hline & .00 & 1.00 & \\
\hline Step 1 PGCG.00 & 2 & 3 & 40.0 \\
\hline 1.00 & 0 & 57 & 100.0 \\
\hline
\end{tabular}

\section{Sumber: Output SPSS.}

etepatan Model Variabel Dependen Terhadap Nilai Observasinya 
Table 6. menjelaskan tentang estimasi ketepatan model variabel dependen terhadap nilai observasinya. Model yang sempurna akan menunjukan nilai observasi peramalan sebesar $100 \%$. Table 4.18 menunjukan nilai sebesar 95.2 yang berarti bahwa ketepatan model ini sebesar $95.2 \%$.

\begin{tabular}{lcccccr}
\hline & B & S.E. & Wald & df & Sig. & Exp(B) \\
\hline Step1a Per_Piut & -.082 & .091 & .805 & 1 & .370 & .922 \\
$\quad$ Per_Pers & .122 & .188 & .418 & 1 & .518 & 1.129 \\
Per_AT & -.350 & .408 & .735 & 1 & .391 & .705 \\
Per_TA & 1.389 & 2.389 & .338 & 1 & .561 & 4.012 \\
Komitmen & 4.510 & 1.590 & 8.047 & 1 & .005 & 90.952 \\
PI & -.305 & 1.652 & .034 & 1 & .854 & .737 \\
Constant & -.105 & 1.527 & .005 & 1 & .945 & .900 \\
\hline
\end{tabular}

Sumber: Output SPSS.

Tabel 7. menjelaskan nilai signifikansi setiap variabel independen terhadap variabel dependen. Variabel independen audit manajemen terdiri dari perputaran piutang nilai signifikansinya sebesar 0.370 , perputaran persedian nilai signifikansinya sebesar 0.518 , perputaran aset tetap nilai signifikansinya sebesar 0.391 , perputaran aset tetap nilai signifikansinya sebesar 0.561 , komitmen organisasional manajer nilai signifikansinya sebesar 0.005 , pengendalian internal nilai signifikansinya sebesar 0.854. Dari persamaan regresi logistik pada tabel 4.14.dapat dilihat bahwa perusahaan akan menerapkan prinsip-prinsip good corporate governance berhubungan positif dengan audit manajemen, komitmen organisasional manjer, dan pengendalian internal.

Hasil penelitian ini menyatakan bahwa ada hubungan positif setiap variabel independen dengan variabel dependen. (a) audit manajemen yang terdiri dari rasio aktivitas perusahaan berhubungan positif terhadap penerapan prinsip-prinsip good corporate governance pada perusahaan manufaktur, (b) komitmen organisasional manajer berhubungan positif dengan penerapan prinsip-prinsip good corporate governance pada perusahaan manufaktur, (c) pengendalian internal berhubungan positif terhadap penerapan prinsip-prinsip good corporate governance pada perusahaan manufaktur, (d) ada hubungan positif antara audit manajemen, komitmen organisasional manajer, penegendalian internal terhadap penerapan prinsip-prinsip good corporate governance perusahaan manufaktur yang telah terdaftar di Bursa Efek Indonesia.

Sesuai dengan hipotesis yang telah diajukan, maka hasil penelitian ini hanya menerima hipotesis dua $\left(\mathrm{H}_{2}\right)$ adalah komitmen organisasional manajer pengaruh positif dan signifikan terhadap penerapan prinsip-prinsip good corporate governance pada perusahaan manufaktur yang terdaftar di Bursa Efek Indonesia.

Hasil penelitian ini mendukung penelitian yang dilakukan oleh Konzelman (2005) komitmen organisasi memengaruhi terhadap penerapan corporate governace dan manajer berusaha untuk mengutamakan komitmen organisasi untuk meningkatkan hasil perusahaan pada para pegawainya.Dan Wiratno et al. (2013) komitmen organisasi berpengaruh positif dan signifikan terhadap penerapan good governance, hal ini menunjukan bahwa komitmen organisasi memberikan kontribusi yang signifikan terhadap penerapan good governance di KPPN Tegal.

Teori yang digunakan sesuai dengan hasil dari penelitian ini dimana: (a) audit manajemen dirancang untuk membantu dewan komisaris, direksi dan manajemen dalam mencapai pengelolaan yang optimal dalam pelaksaan tugas yang menjadi tanggungjawab mereka dan menilai efisiensi dan ekonomi operasi dan efektivitas dari fungsi-fungsi tersebut dalam mencapai sebuah tujuan (Sawyer, et al. 2005). (b) komitmen organisasional yaitu untuk mewujudkan tujuan organisasi harus berdasar kepercayaan, kerelaan dan loyalitas para anggotanya atas nilainilai organisasi (Taufik dan Kemala, 2013). (c) pengendalian internal yang disusun 
Pengaruh

Audit

Manajemen...

654

oleh manajemen bertujuan untuk mencapai tiga tujuan umum perusahaan yaitu: (1) keandalan pelaporan keuangan, (2) efisiensi dan efektivitas operasi, (3) ketaantan pada hukum dan peraturan (Arens et al. 2008). (d) Good corporate governance adalah suatu sistem dan seperangkat peraturan yang mengatur hubungan antara berbagai pihak yang berkepentingan (stakeholders) yaitu pemegang saham, dewan komisaris, dan dewan direksi demi tercapainya tujuan peruahaan (Zarkasyi, 2008).

\section{SIMPULAN}

Berdasarkan analisis yang telah dilakukan dapat disimpulkan: Variabel independen yaitu audit manajemen terdiri dari rasio aktivitas, komitmen organisasional manajer dan pengendalian internal dapat menjelaskan terhadap variable dependen yaitu penerapan prinsip-prinsip good corporate governance sebesar 49.3\% dan 50.7\% dijelaskan oleh faktor lain. Model regresi logistik menyatakan bahwa data fit dengan model sebesar 95.2\%. Variabel komitmen organisasional manajer adalah satu-satunya yang signifikan dan mampu mempredeksi bahwa perusahaan manufaktur yang terdaftar di Bursa Efek Indonesia akan menerapkan prinsip-prinsip good corporate governance.

Berdasarkan beberapa kesimpulan diatas maka peneliti memberikan saran sebagi berikut: Sebaiknya perusahaan menerapkan prinsip-prinsip good corporate governance secara menyeluruh karena dengan diterapkannya prinsip-prinsip good corporate governanceakan memberikan dampak positif terhadap keberlangsugan perusahaan. Penelitian dilakukan dengan menggunakan beberapa tahun laporan tahunan sehingga dapat melihat akan konsistenan perusahaan manufaktur terhadap penerapan prinsip-prinsip good corporate governance. Penelitian selanjutnya menggunakan tambahan data primer.

\section{DAFTAR PUSTAKA}

Agoes, Sukrisno. 2012, Auditing Petunjuk Praktis Pemeriksaan Akuntan oleh Akuntan Publik. Salemba Empat. Jakarta.

Agustine, Yvonne. dan Robert Kristaung. 2013. Metodologi Penitian Bisnis dan Akukuntansi. PT. Dian Rakyat. Jakarta.

Arens, A.A, Elder, R.J, Beasly, M.S. 2008. Auditing and Assurance Services. Twelfth Edition. Prentice Hall.Inc. Diterjemahkan oleh Herman Wibowo. 2008. Erlangga. Jakarta.

Kementerian Keuangan RI Bapepam-LK. 2010. Kajian Tentang Pedoman Good Corporate Governance Di Negara-Negara Anggota ACMF.

Forum for Corporate Governance in Indonesia. (2001). Corporate Governance: Tata Kelola Perusahaan. Edisi Ketiga. Jakarta: Prentice Hall.

Ghozali, Imam. 2011. Analisis Multivariat dengan Program SPSS. UNDIP. Semarang.

Hariyati, Rini Mariani dan Ongki Dessy Oliviani. 2013. "Pengaruh Audit Manajemen dan Pengendalian Internal Terhadap Kinerja Perusahaan dengan Good Corporate Governance Sebagai Variabel Intervening (Studi pada PT. Jamsostek (Persero) Divisi Regional VI Jawa Timur)". Proceeding Seminar Nasional dan Call For Papers Sancall 2013. Surakarta.

Indriantoro, Nur, dan Bambang Supomo. 2009. Metode Penelitian Bisnis: untuk Akuntansi dan Manajemen. BPFE-Yogyakarta.Yogyakarta. 
Konzelman, S. 2005. Corporate Governance, Stakeholding and the Nature of Employment Relations Within the Firm. Working paper/ Centre for Business, University of Cambrige.

Meyti dan Lusiana Devita. 2011. "Pengaruh Penerapan Good Corporate Governance (GCG) Terhadap Kinerja Keuangan Perusahaan: Studi Empiris Pada Perusahaan Go Public yang Termasuk Sepuluh Besar Menurut Corporate Governance Perception Index (CGPI) Di Bursa Efek indonesia". Jurnal Hukum Bisnis dan Investasi, Volume 3, (1): 71-89 Universitas Kristen Maranatha. Bandung.

Protolo, Suryo. 2008. "Pengaruh Audit Manajemen, Komitmen Organisasional Manajer, Pengendaian Intern Tehadap Penerapan Prinsip-Prinsip Good Corporate Governance Dan Kinerja Badan Usaha Milik Negara Di Indonesia". Jurnal Akuntansi dan Investasi. Volume 9, (1): 15-32 Universitas Muhammadiyah. Yogyakarta.

Ristiani, Ni Made Asih, Ni Kadek Sinarwati, dan Edy Sujana. 2014. "Pengaruh Sistem Pengendalian, Pengelolaan Keuangan, dan Komitmen Organisasi Terhadap Penerapan Good Governance (Studi Kasus pada Satuan Kerja Perangkat Daerah Kabupaten Tabanan)". Jurnal Akuntansi Program S1, Volume 2, (1).

Saptapradipta, Patricia. 2014. "Pengaruh Audit Internal dan Pengendalian Internal terhadap pelaksanaan Good Governance (Studi pada Badan Layanan Umum Universitas Brawijaya)". Jurnal Universitas Brawijaya. Malang.

Sawyer, L.B., Dittenhofer, M.A., dan Schemer, J.H. 2003. Sawyer's Internal Audit. Fifth Edition. Altamonte Springs. Florida. Diterjemahkan oleh Desi Adhariani dan Ika Permatasari. 2005. Salemba Empat. Jakarta.

Sugiyono. 2014. Metode Penelitian Kuantitatif Kualitatif dan R\&D. Alfabeta. Bandung.

Taufik, Taufeni dan Dian Kemala. 2013. "Pengaruh Pemahaman Prinsip-Prinsip Good Governance, Pengendalian Intern dan Komitmen Organisasi Terhadap Kinerja SektorPublik". Pekbis Jurnal. Volume, 5 (1): 51-63. Universitas Riau.

Widjaja, Ferlencia dan Ronny H. Mustamu. 2014." Pengaruh Sistem Pengendalian Internal Terhadap Implementasi Prinsip-Prinsip Good Coporate Governance Pada Perusahaan Industri Keramik”. AGORA. Volume 2, (1): 8.

Wiratno, Adi, Umi Pratiwi, dan Nurkhikmah. (2013). "Pengaruh Budaya Organisasi, Gaya Kepemimpinan, Komitmen Organisasi, Dan Pengendalian Internal Terhadap Penerapan Good Governance Serta Implikasi Kinerja" Jurnal.Volume 3, (1) Proceeding Seminar Nasional dan Call For Paper (SCA3). Universitas Jendral Soediman.

Zarkasi, Wahyudin. 2008. Good Corporate Governance pada Badan Usaha Manufaktur, Perbankan, Jasa Keuangan Lainnya. Alfabeta: Bandung. 
